\title{
Functional consequences of naturally occurring variants of human hexokinase II
}

\author{
M. Malkki ${ }^{1,2}$, M. Laakso ${ }^{1}$, S. S. Deeb ${ }^{2}$ \\ ${ }^{1}$ Department of Medicine, Kuopio University Hospital, Kuopio, Finland \\ ${ }^{2}$ Departments of Medicine and Genetics, University of Washington, Seattle, Washington, USA
}

\begin{abstract}
Summary Hexokinase II (HKII) catalyses a key step in glucose metabolism and can be regarded as a candidate gene for insulin resistance and type 2 (non-insulin-dependent) diabetes mellitus. We observed previously four amino acid substitutions among Finnish type 2 diabetic patients: Gln142His, Ala314Val; $0.9 \%, \operatorname{Arg} 353 \mathrm{Cys} ; 2.7 \%$ and Arg775Gln; $2.7 \%$. The Arg775Gln mutation was also observed in normal control subjects $(2.1 \%)$ and the Gln142His substitution was found in both Type II diabetic and normal subjects with similar frequencies $(\sim 20 \%)$. Since Gln at position 142, Ala at 314 and Arg at 775 are present in human and rat hexokinases and could be im-
\end{abstract}

portant for structure and function of the enzyme, we generated all four substitutions by site-directed mutagenesis and expressed them in E.coli. None of these substitutions had any effect on HKII catalytic activity, $\mathrm{K}_{\mathrm{m}}$ or $\mathrm{V}_{\max }$ for glucose values in vitro. Thus unless these substitutions have an impact on enzyme activity or regulation in vivo, it is unlikely that these substitutions contribute to the aetiology of Type II diabetes. [Diabetologia (1998) 41: 1205-1209]

Keywords Hexokinase II, glucokinase, Type II (noninsulin-dependent) diabetes mellitus, mutagenesis.
Hexokinases (HKI-IV, EC 2.7.1.1) play a central role in intracellular glucose metabolism by catalysing the phosphorylation of glucose to glucose-6-phosphate [1]. Hexokinases I-III are $100 \mathrm{kDa}$ proteins, have a low $\mathrm{K}_{\mathrm{m}}$ for glucose and are subject to allosteric inhibition by glucose-6-phosphate (Glc-6-P). The fourth $\mathrm{HK}$, also known as glucokinase, is a $50 \mathrm{kDa}$ protein, has a high $\mathrm{K}_{\mathrm{m}}$ for glucose and is not inhibited by Glc-6-P at physiological concentrations. The high sequence similarity between the $\mathrm{N}$ - and $\mathrm{C}$-terminal halves of mammalian hexokinases I-III and glucokinase and the yeast hexokinase has lead to the hypothesis that this gene family has evolved from an

Received: 6 March 1998 and in revised form: 18 May 1998

Corresponding author: Dr. S.S. Deeb, Genetics Department, Box 357360, University of Washington, Seattle, Wash. 98195, USA

Abbreviations: GK, Glucokinase; HKI-III, hexokinase I-III; HK-B, hexokinase B; PCR, polymerase chain reaction; Glc-6$\mathrm{P}$, glucose-6-phosphate. ancestral gene by tandem gene duplication and fusion.

The HKII gene encodes a protein of 917 amino acids. The $\mathrm{N}$ - and $\mathrm{C}$-terminal halves of human and rat hexokinases are catalytically active and inhibited for feed-back by Glc-6-P [2, 3]. In contrast, the N-terminal half of rat brain HKI contains the allosteric regulatory site for Glc-6-P and the C-terminal half contains the catalytic site $[4,5]$.

HKII is mainly expressed in tissues sensitive to insulin such as skeletal and cardiac muscle and adipose tissue [6]. It is therefore considered to be a potential candidate gene for type 2 (non-insulin-dependent) diabetes mellitus and insulin resistance [7]. Reduced glucose oxidation and non-oxidation [8, 9], Glc-6-P [10-12] and HKII mRNA and activity levels [13] were observed in skeletal muscle of patients with Type II diabetes.

Both sibling-pair [14] and population association [15] studies in French and Japanese subjects suggested that polymorphic markers at the HKII locus are not associated with Type II diabetes. Another study 
in Pima Indians [16] did not detect either a linkage or an association of HKII with insulin resistance and type 2 diabetes.

The human HKII gene has been screened for variants in the coding region in patients with Type II diabetes and normal subjects [17-22]. A total of seven missense substitutions (Gln142His, Leu148Phe, Ala314Val, Arg353Cys, Arg497Gln, Arg775Gln and Arg844Lys), eight silent base substitutions (Ile201, Asp251, Glu304, Thr331, Leu586, Asn692, Pro736, Leu766) and several intronic nucleotide substitutions were found. The Gln142His substitution was very common and found at an equal frequency (approximately $20 \%$ ) among type 2 diabetic and normal subjects. This polymorphism was not associated with insulin resistance or type 2 diabetes [19,20]. The other HKII sequence variants are rare and found in only $1-3 \%$ of Type II diabetic patients. The Arg775Gln is also found among control subjects.

In this study, we have assessed the consequences of amino acid substitutions in HKII that we found among the Finnish type 2 diabetic patients and normal subjects on HKII catalytic activity. We observed that none of the substitutions had any detectable effect on catalytic activity in vitro.

\section{Materials and methods}

Construction of hexokinase II expression vector pET-hHKII. Total RNA from human adipose tissue was prepared with guanidinium isothiocyanate-phenol-chloroform method [23]. Total cellular RNA was used as template to synthesize first strand cDNA by SuperScript kit (BRL, Bethesda Research Laboratories, LifeTechnologies, Grand Island, N. Y., USA) according to manufacturer's protocol. This cDNA was used as template to amplify human HKII cDNA (nucleotides 108-2876, numbered according to reference [24]) using the Expand Long Template polymerase chain reaction (PCR) system (Boehringer Mannheim, Indianapolis, Ind., USA) according to the manufacturer's protocol. Primers HKII Nde5' and HKII Nde3' (Table 1) were used to create NdeI restriction sites on both ends of HKII cDNA. The amplified product was cloned into the NdeI site of the expression vector pET28c $(+)$ (Novagen, Madison, Wis., USA), which carries a His-Tag oligohistidine domain for expression in the C-terminal side of the target protein. The entire HKII coding sequence in the resultant clone (pET-hHKII) was verified by sequencing (Sequenase kit, Amersham, Arlington Heights, Il, USA).

Oligonucleotide directed mutagenesis of HKII. Oligonucleotide directed mutagenesis was used to create the HKII mutations Gln142His (CA $A$ - > CAT), Ala314Val (GCC-> GTC), Arg353Cys (CGT- > TGT) and Arg775Gln (CGG- > CAG). $H K I I$ cDNA segments containing each of the substitutions were first cloned into vectors pGEM3Zf $(+)$ (Promega, Madison, Wis., USA) or pBSII SK + (Sratagene, LaJolla, Calif., USA) for production of single-stranded DNA [25]. Mutagenesis was carried out according to Kunkel [26]. The oligonucleotides used to create substitution are given in Table 1 . All mutated clones were verified by sequencing and cloned back into their respective positions in plasmid pET-hHKII for expression in E.coli.
Table 1. Sequence of primers used in PCR and in vitro mutagenesis

\begin{tabular}{ll}
\hline Primer & Sequence $\cdot\left(5^{\prime}-3^{\prime}\right)$ \\
\hline HKII Nde5' & $\begin{array}{l}\text { GGAATTCCATATGCGCGGCAGGAT- } \\
\text { GATTGCCC }\end{array}$ \\
HKII Nde3' & $\begin{array}{l}\text { GGAAGTCCATATGGGGGTTC- } \\
\text { TATCGCTGTCCAG }\end{array}$ \\
HKII Mut4 & ATGGATAAGCTACATATCAAAGACAAG \\
HKII 8MF & CCTGGTGAAGATGGTCAAGGAG- \\
HKII 8MR & GAGCTGC \\
HKII Mut9 & CAGGCTCCTCCTTGACCATCTTCAC- \\
HKII Mut16 & CTTGTCTTGAGCTGCTCTGAGATG \\
\hline
\end{tabular}

One of the clones containing the Ala314Val substitution was found to have three other sequence alterations which had occurred inadvertently during the cloning. One was a 3 bp deletion which resulted in the deletion of $\mathrm{Phe}^{293}$. The other two were single base substitutions that resulted in Glu294Val and Ile297Val amino acid substitutions. This clone was called 3 MUThk 8 and was used as a negative control for expression of active HKII in E.coli.

The Ala314Val substitution was created by using QuikChange Site-directed Mutagenesis kit (Stratagene, LaJolla, Calif., USA) basically following manufacturer's protocol. PCR was done using template pET-hHKII, primers HKII 8MF and HKII 8MR (Table 1) and Expand High Fidelity enzyme (Boehringer Mannheim, Indianapolis, Ind., USA). Mutated clones were screened by single strand conformation polymorphism (SSCP) analysis [27] and sequencing.

Expression of HKII in E.coli. Plasmids with wild-type or mutant HKII cDNA were transformed into E.coli strain HMS174(DE3)pLysS [28]. A 10-ml inoculum of the transformed strain in M9ZB medium [28] supplemented with $30 \mathrm{mg} / \mathrm{l} \mathrm{kanamycin}$ and $25 \mathrm{mg} / \mathrm{l}$ chloramphenicol, was grown overnight and then added to $250 \mathrm{ml}$ of the same medium. The culture was grown at $37^{\circ} \mathrm{C}$ to an OD at $600 \mathrm{~nm}$ of 0.4 , and isopropyl-1-thio- $\beta$-D-galactopyranoside (IPTG) was then added to a final concentration of $1 \mathrm{mmol} / \mathrm{l}$. Cultures were incubated with vigorous aeration for an additional $2 \mathrm{~h}$ at ambient temperature $\left(20-24^{\circ} \mathrm{C}\right)$

Cells were collected by centrifugation and resuspended in lysis buffer (50 mmol/l Tris-HCl, pH 8.0, $5 \mathrm{mmol} \mathrm{MgCl}_{2}$, $100 \mathrm{mmol} / 1 \mathrm{KCl}, 1 \mathrm{mg} / \mathrm{ml}$ lysozyme, $0.1 \%$ Triton, $2.5 \mu \mathrm{g} / \mathrm{ml}$ leupeptin, $50 \mu \mathrm{mol} / \mathrm{l}$ phenylmethanesulphonyl fluoride [29]). The resuspended cells were incubated on ice for $30 \mathrm{~min}$ and subjected to three cycles of freezing and thawing to lyse the cells. Bacterial chromosomal DNA was sheared by sonication. The bacterial lysates were cleared of cellular debris by centrifugation. The supernatant containing the expressed HKII protein was applied to HisBind resin columns (Novagen, Madison, Wis., USA) and purified according to the manufacturer's protocol.

$S D S-P A G E$ and protein determination. The E.coli cell lysates and column purified HKII protein preparations were subjected to sodium dodecyl sulphate (SDS)-polyacrylamide (8\%) gel electrophoresis [30]. Gels were stained with Coomassie Brilliant Blue. The protein concentration in lysates and column fractions was determined by the Bradford assay [31] using bovine serum albumin as a standard. 


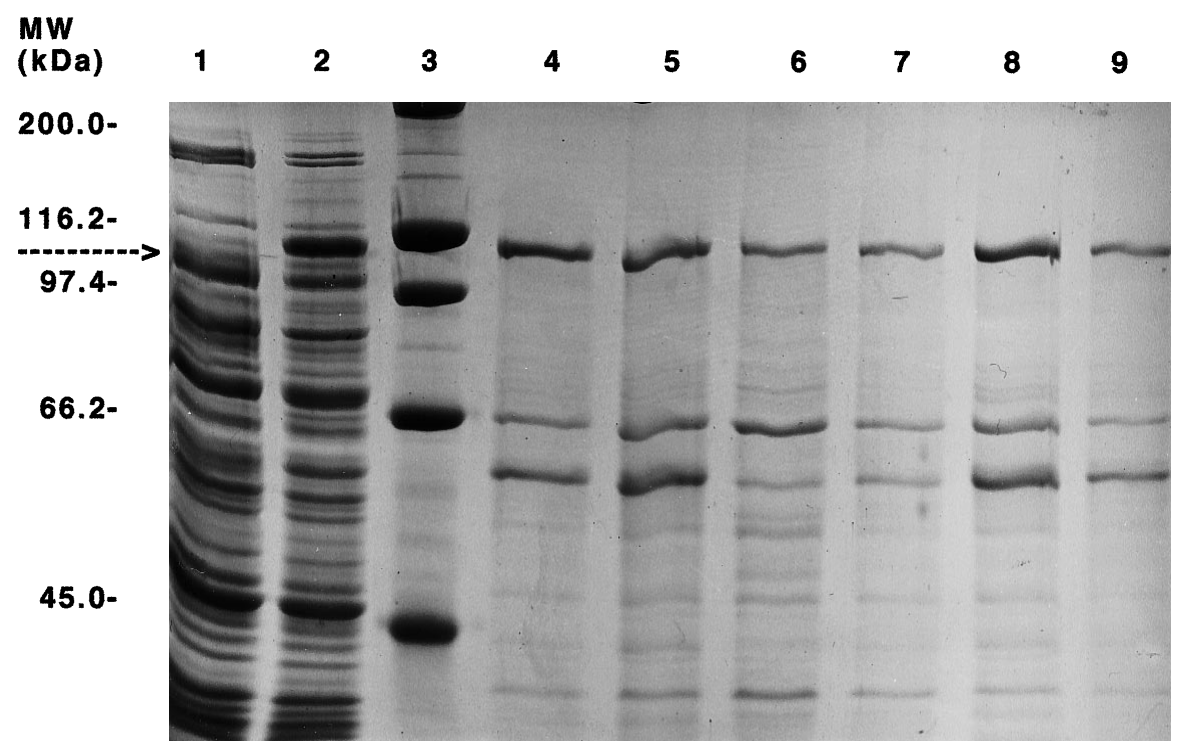

Fig. 1. SDS-polyacrylamide gel electrophoresis of total cellular proteins and purified HKII. Lane 1, total proteins expressed from HMS174DELysS-HKIIcDNA in E. coli without induction with IPTG. Lane 2, proteins from HMS174DELysS-HKIIcDNA culture after $2 \mathrm{~h}$ induction with IPTG. Lane 3, protein standards. Lanes 4-9, normal HKII, variant HKII Gln142His, Ala413Val, Arg353Cys, Arg775Gln, 3MUThk8 proteins purified from E. coli extracts on His-Bind columns. HKII protein is marked with an arrow

Table 2. Kinetic measurements of the wild-type and variant hexokinases. Human hexokinase II purified from extracts of E. coli transformed with cDNAs encoding either wild-type or variant HKII was assessed for various kinetic parameters. The mean $\pm S E$ was determined from three to four separate preparations of each protein

\begin{tabular}{llll}
\hline Enzyme & $\begin{array}{l}\text { Specific activity } \\
\mathrm{mU} / \mu \mathrm{g}\end{array}$ & $\begin{array}{l}\mathrm{Km} \text { for glucose } \\
\mathrm{mmol} / \mathrm{l}\end{array}$ & $\begin{array}{l}\mathrm{Vmax} \\
\mathrm{nmol} / \mathrm{min}\end{array}$ \\
\hline normal & $4.0 \pm 0.9$ & $0.11 \pm 0.03$ & $23.4 \pm 3.0$ \\
Gln142His & $3.5 \pm 0.8$ & $0.10 \pm 0.03$ & $19.6 \pm 3.4$ \\
Ala314Val & $3.6 \pm 1.2$ & $0.08 \pm 0.02$ & $20.5 \pm 6.7$ \\
Arg353Cys & $2.6 \pm 0.8$ & $0.14 \pm 0.05$ & $17.3 \pm 8.0$ \\
Arg775Gln & $4.3 \pm 0.7$ & $0.13 \pm 0.01$ & $24.8 \pm 1.7$ \\
\hline
\end{tabular}

Assay of catalytic activity and heat stability. 5-10 $\mu \mathrm{g}$ of column purified wild-type and variant hexokinase protein preparations were assayed immediately after elution of the HisBind column for hexokinase activity at ambient temperature in a total vol-

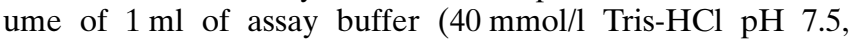
$20 \mathrm{mmol} / \mathrm{l} \mathrm{MgCl}_{2}, 0.9 \mathrm{mmol} / \mathrm{l} \mathrm{NADP}, 2 \mathrm{mmol} / \mathrm{l} \mathrm{ATP}, 2 \mathrm{mmol} / \mathrm{l}$ EDTA, 0.2-2.5 mmol/1 glucose, $1 \mathrm{U}$ glucose-6-phosphate dehydrogenase) (modified from reference [32]). The reaction was followed by measuring the increase in absorbance at 340 $\mathrm{nmol} / \mathrm{l}$ for $5 \mathrm{~min}$. One unit of hexokinase activity is defined as the amount of enzyme which catalyses the formation of $1 \mu \mathrm{mol}$ of NADPH in $1 \mathrm{~min}$ at ambient temperature. The $\mathrm{K}_{\mathrm{m}}$ and $\mathrm{V}_{\max }$ for glucose were determined from double-reciprocal (Lineweaver-Burk) plots.

Heat stability of the wild-type and exon 9 (Arg353Cys) variant was tested by treating 5-10 $\mu \mathrm{g}$ of column purified protein for 10,20 or $30 \mathrm{~min}$ at room temperature or at $30^{\circ} \mathrm{C}$.

\section{Results and discussion}

Wild-type and mutant human HKII proteins were expressed in E.coli. A large fraction of the expressed HKII proteins were found to accumulate as insoluble aggregates, perhaps as a result of overexpression. However, significant amounts were also found in the supernatant. Soluble HKII was highly purified by affinity chromatography.

Induction of cells containing pET-hHKII resulted in accumulation of a $100 \mathrm{kDa}$ protein that was not present in the non-induced cell culture (Fig.1, lanes 1 and 2), and thus this protein can reasonably be assumed to correspond to hexokinase II. Mutant HKII proteins were purified to the same degree and showed the same electrophoretic mobility on sodium dodecyl sulphate (SDS) polyacrylamide gels as the wild-type protein (Fig. 1, lanes 4 to 8 ). The co-elution of some bacterial proteins seen also in Figure 1 is a well-known phenomenon with this expression system (protocol manual, Novagen, Madison, Ind., USA). These proteins did not contribute to HKII activity measurements as evidenced by the lack of detectable activity in extracts of induced E. coli cells transformed with HKII mutant 3MUThk8 (Fig. 1, lane 9) which produced an inactive protein.

The results of kinetic measurements on wild-type and mutant enzymes are given in Table 2 . The wildtype enzyme had a $\mathrm{Km}$ value of $0.11 \pm 0.03 \mathrm{mmol} / \mathrm{l}$ for glucose which is comparable with that determined previously $(0.14-0.2 \mathrm{mmol} / 1$ [6], $0.23-0.28 \mathrm{mmol} / \mathrm{l}$ [33], $0.19 \mathrm{mmol} / 1$ [29], $0.34 \pm 0.06 \mathrm{mmol} / 1$ [2]). None of the mutant HKII enzymes showed a statistically significant difference in specific activity, $K_{m}$ and $\mathrm{V}_{\max }$ for glucose values from the wild-type enzyme. Since the expressed proteins had some bacterial proteins, comparison of specific activities is uncertain.

Heat stability of the in vitro expressed HKII with the Arg353Cys substitution was examined for heat 
Table 3. Comparsion of the residues 142, 314, 353 and 775 of human HKII with the corresponding residues in the hexokinase family

\begin{tabular}{|c|c|c|c|c|c|c|c|c|c|c|}
\hline \multirow[t]{2}{*}{ Codon } & \multicolumn{2}{|l|}{ HKI } & \multicolumn{2}{|l|}{ HKII } & \multicolumn{2}{|l|}{ HKIII } & \multicolumn{2}{|l|}{ GK } & \multirow{2}{*}{$\begin{array}{l}\text { GK } \\
\text { yeast }\end{array}$} & \multirow{2}{*}{$\begin{array}{l}\text { HK-B } \\
\text { yeast }\end{array}$} \\
\hline & human & rat & human & rat & human & rat & human & rat & & \\
\hline 142 & Lys & Lys & Gln & Gln & Gln & Tyr & Gln & Gln & His & Gln \\
\hline 314 & Ala & Ala & Ala & Ala & Ala & Ser & Val & Val & His & Tyr \\
\hline 353 & Lys & Lys & Arg & Tyr & His & His & Tyr & His & Gly & Asp \\
\hline 775 & Thr & Pro & Arg & Arg & Cys & Cys & Gln & Gln & Gln & Cys \\
\hline
\end{tabular}

stability relative to the wild-type enzyme expressed under the same conditions. Activity of both the wildtype and the variant enzyme decreased by $90 \%$ and $70 \%$ after a $10 \mathrm{~min}$ incubation at $30^{\circ} \mathrm{C}$ or $30 \mathrm{~min}$ incubation at room temperature, respectively.

With the exception of the polymorphic Gln142His, the amino acid substitutions investigated in this study were observed only in the Finnish population [17]. The Ala314Val substitution was found in $0.9 \%$, the Arg353Cys and the Arg775Gln mutation in $2.7 \%$ of Type II diabetic patients. The Arg775Gln mutation was also found in control subjects (2.1\%) [17].

Based on amino acid sequence comparisons among various hexokinases and on structure/function studies that have been carried out on the yeast hexokinase and on X-ray crystallographic studies [34, 35 ], the putative glucose and ATP binding domains have been assigned [2, 3, 36, 37]. None of the amino acid substitutions examined in this study fall within any of these domains.

Glutamine at position 142 is conserved in human and rat HKII, glucokinase and human HKIII, suggesting an important role in structure and function of the enzyme. Residue 142 is in close proximity to the Ser at position 155 (conserved in all hexokinases), which is postulated to hydrogen bond with glucose in the yeast hexokinase [35]. Mutagenesis studies in rat HKI [38] and tumour hexokinase [37], however, indicated that substitutions of this residue has no effect on catalytic activity. The human and rat HKI have lysine at position 142 (Table 3) and the yeast glucokinase has histidine at the corresponding position (residue 145) [1]. All these amino acids residues have quite similar hydrophobicity indices of between -3.2 and -3.9 [39]. These results are consistent with our finding that the Gln142His substitution has no impact on catalytic activity.

Alanine at position 314 is conserved among the human and rat HKI, HKII and human HKIII, but not in the human and rat glucokinases, which have valine at the corresponding position. It appears that having a hydrophobic residue at position 314 is evolutionarily conserved among all hexokinases and, therefore, may have structural (stability, for example) or functional significance. It is possible, however, that the larger and more hydrophobic valine side chain is more appropriate for HKI-HKIII than for glucoki- nase. Our results indicate that at least in the HKII synthesized in E. coli, the advantage of having Val, if any was not detectable.

Argine at position 353 is conserved in both halves of human HKII but not in the rat enzyme which has Tyr. Moreover, human and rat HKI and HKIII have Lys and His, respectively; human and rat glucokinases have Tyr and His, respectively at the corresponding position. The Arg, Lys, His and Tyr residues have similar hydrophobicity indices and, therefore the above differences among hexokinases may be well tolerated. The Arg353Cys, however, is not a chemically conservative substitution (a change in hydrophobicity index from -4.5 to +2.5 ). In addition, the new Cys residue could potentially form a disulphide bond with other Cys residues at positions 368, 377 or 385 , which would result in significant conformational changes. Therefore, it was surprising to find that the in vitro protein with this substitution exhibited the kinetic properties and stability of the wildtype protein expressed in the same manner.

Arginine at position 775 is common to only human and rat HKIIs (Table 3 ). The arginine to glutamine substitution is relatively conservative, having hydrophobicity indices of -4.5 and -3.5 , respectively [39]. The human and rat glucokinases have glutamine at the corresponding position. Our results are consistent with the notion that this substitution has no effect on catalytic activity of the enzyme.

In conclusion, based on results of expression of the variant and wild-type HKII enzymes in vitro, it seems unlikely that the amino acid variants we observed among Finnish Type II diabetic patients contribute significantly to the aetiology of this disease.

\section{References}

1. Wilson JE (1995) Hexokinases. Rev Physiol Biochem Pharmacol 126: 95-198

2. Ardehali H, Yano Y, Printz RL et al. (1996) Functional organization of mammalian hexokinase II. Retention of catalytic and regulatory functions in both the $\mathrm{NH}_{2}$ and COOH-terminal halves. J Biol Chem 271: 1849-1852

3. Kogure K, Yamamoto K, Majima E, Shinihara Y, Yamashita K, Terada H (1996) Alteration of enzyme function of the type II hexokinase C-terminal half of replacements of 
restricted regions of corresponding regions of glucokinase. J Biol Chem 271: 15230-15236

4. Schirch M, Wilson JE (1987) Rat brain hexokinase: location of the substrate hexose binding site in a structural domain at the C-terminus of the enzyme. Arch Biochem Biophys 254: 385-396

5. White TK, Wilson JE (1987) Rat brain hexokinase: location of allosteric regulatory site in a structural domain at the N-terminus of the enzyme. Arch Biochem Biophys 259: 402-411

6. Katzen HM (1967) Multiple forms of mammalian hexokinase and their significance in the action of insulin. Adv Enzyme Regul 5: 335-355

7. Granner DK, O'Brien RM (1992) Molecular physiology and genetics of NIDDM. Importance of metabolic staging. Diabetes Care 15: 369-395

8. Felber JP, Golay A, Felley C, Jequier E (1988) Regulation of glucose storage in obesity and diabetes: metabolic aspects. Diabetes Metab Rev 4: 691-700

9. Del Prato S, Bonadonna RC, Bonora E et al.(1993) Characterization of cellular effects of insulin action in type 2 (non-insullin-dependent) diabetes mellitus. J Clin Invest 91: 484-494

10. Shulman GI, Rothman DL, Jue T, Stein P, DeFronzo RA, Shulman RG (1990) Quantitation of muscle glycogen synthesis in normal subjects and subjects with non-insulin-dependent diabetes by $13^{\circ} \mathrm{C}$ nuclear magnetic resonance spectroscopy. N Engl J Med 322: 223-228

11. Rothman DL, Shulman RG, Shulman GI (1992) ${ }^{31} \mathrm{P}$ magnetic resonance measurements of muscle glucose-6-phosphate. J Clin Invest 89: 1069-1075

12. Rothman DL, Magnusson I, Cline G et al. (1995) Decreased muscle glucose transport/ phosphorylation is an early defect in the pathogenesis of non-insulin-dependent diabetes mellitus. Proc Natl Acad Sci USA 92: 983-987

13. Vestergaard H, Bjorbaek C, Hansen T, Larsen FS, Granner DK, Pedersen O (1995) Impaired activity and gene expression of hexokinase II in muscle from non-insulin-dependent diabetes mellitus patients. J Clin Invest 96: 2639-2645

14. Vionnet N, Hani EH, Lesage S et al. (1997) Genetics of NIDDM in France. Studies with 19 candidate genes in affected sib pairs. Diabetes 46(6):1062-1068

15. Yagi T, Nishi S, Hinata S, Murakami M, Yoshimi T (1996) A population association study of four candidate genes (hexokinase II, glucagon-like peptide-1 receptor, fatty acid binding protein-2, and apolipoprotein C-II) with type 2 diabetes and impaired glucose tolerance in Japanese subjects. Diabet Med 13(10):902-907

16. Ardehali H, Tiller GE, Printz RL, Mochizuki H, Prochazka M, Granner DK (1996) A novel (TA)n polymorphism in the hexokinase gene: application to noninsulin-dependent diabetes mellitus in Pima Indians. Hum Genet 97: 482-485

17. Laakso M, Malkki M, Deeb SS (1995) Amino acid substitutions in hexokinase II among patients with NIDDM. Diabetes 44: 330-334

18. Laakso M, Malkki M, Kekäläinen P, Kuusisto J, Deeb SS (1995) Polymorphisms of the human hexokinase II gene: lack of association with NIDDM and insulin resistance. Diabetologia 38: 617-622

19. Echwald SM, Bjorbaek C, Hansen T et al. (1995) Identification of four amino acid substitutions in hexokinase II and studies of relationships to NIDDM, glucose effectiveness, and insulin sensitivity. Diabetes 44: 347-353

20. Vidal-Puig A, Printz RL, Stratton IM, Granner DK, Moller DE (1995) Analysis of the hexokinase II gene in subjects with insulin resistance and NIDDM and detection of $\mathrm{Gln}^{142}$ - > His substitution. Diabetes 44: 340-346
21. Lehto M, Huang X, Le Beau MM et al. (1995) Human hexokinase II gene: exon-intron organization, mutation screening in NIDDM, and its relationship to muscle hexokinase activity. Diabetologia 38: 1466-1474

22. Taylor RW, Printz RL, Armstrong M et al. (1996) Variant sequences of the hexokinase II gene in familial NIDDM. Diabetologia 39: 322-328

23. Chomczynski P, Sacchi N (1987) Single step method of RNA isolation by acid guanidium thiocyanate-phenolcholoroform extraction. Anal Biochem 162: 156-159

24. Deeb SS, Malkki M, Laakso M (1993) Human hexokinase II: sequence and homology to other hexokinases. Biochem Biophys Res Commun 197: 68-74

25. Vieira J, Messing J (1987) Production of single-stranded plasmid DNA. Methods Enzymol 153: 3-11

26. Kunkel TA, Bebenek K, McClary J (1991) Efficient site-directed mutagenesis using uracil-containing DNA. Methods Enzymol 204: 125-139

27. Orita M, Suzuki Y, Sekiya T, Hayashi K (1989) Rapid and sensitive detection of point mutations and DNA polymorphisms using the polymerase chain rection. Genomics 5: 874-879

28. Studier FW, Rosenberg AH, Dunn JJ, Dubendorff JW (1990) Use of T7 RNA polymerase to direct expression of cloned genes. Methods Enzymol 185: 60-89

29. Printz RL, Koch S, Potter LR, O'Doherty RM, Tiesinga SM, Granner DK (1993) Hexokinase II mRNA and gene structure, regulation by insulin and evolution. J Biol Chem 268: 5209-5219

30. Sambrook J, Fritsch EF, Maniatis T (1989) Molecular cloning. A laboratory manual. 2nd edn. Cold Spring Harbor Laboratory Press, Cold Spring Harbor, N. Y., pp 6.36-6.44

31. Bradford M (1976) A rapid and sensitive method for the quantitation of microgram quantities of protein utilizing the principle of protein-dye binding. Anal Biochem 72: 248-254

32. Mandarino JL, Printz RL, Cusi KA et al. (1995) Regulation of hexokinase II and glycogen synthase mRNA, protein, and activity in human muscle. Am $\mathrm{J}$ Physiol 269:E701-E708

33. Grossbard L, Schimke RT (1966) Multiple hexokinases of rat tissues. Purification and comparison of soluble forms. J Biol Chem 241: 3546-3560

34. Bennett WS Jr, Steitz TA (1980) Structure of a complex between yeast hexokinase A and glucose. Configuration with the native hexokinase $\mathrm{B}$ monomer and dimer. $\mathrm{J}$ Mol Biol 149: $211-230$

35. Harrison R (1985) Crystallographic refinement of two isozymes of yeast hexokinase and relationship of structure to function. PhD thesis, Yale University, New Haven, Conn.

36. Arora KK, Filburn CR, Pedersen PL (1991) Glucose phosphorylation. Site-directed mutations which impair the catalytic function of hexokinase. J Biol Chem 266: 5359-5362

37. Arora KK, Filburn CR, Pedersen PL (1993) Structure/ function relationships in hexokinase. Site-directed mutational analyses and characterization of overexpressed fragments implicate different functions for the $\mathrm{N}$ - and C-terminal halves of the enzyme. J Biol Chem 268: 18259-18266

38. Baijal M, Wilson JE (1992) Functional consequencies of mutation of highly conserved serine residues, found at equivalent positions in the $\mathrm{N}$ - and $\mathrm{C}$-terminal domains of mammalian hexokinases. Arch Biochem Biophys 298: 271-278

39. Kyte J, Doolittle R (1982) A simple method for displaying the hydropathic character of a protein. J Mol Biol 157: $105-132$ 